\title{
White South Africa's early external relations*
}

\author{
David Tothill \\ Retired Historian, South Africa. E-mail: f.d.tothill@pixie.co.za \\ Accepted 5 July, 2013
}

\begin{abstract}
White supremacist South Africa's Department of External Affairs was set up in 1927 to demonstrate the country's political independence of the United Kingdom. It operated under various names until the régime gave way to a democratically-elected government in 1994. Unlike its counterparts in Australia, Canada and the United Kingdom, which had long included in their structures sections of historians tasked to research those countries' diplomatic history, the South African department was never historically-aware. There was even a time in the 1980s when it compelled the National Archives to prohibit scholarly access to all foreign affairs records from the time of Union in 1910 (Pienaar, 1987). It is, therefore, not without irony that in 1990, during the régime's death throes, departmental management itself commissioned a history of the department. After several hiccups including a retired official's lengthy, self-imposed search for a publisher, this was eventually published. This article examines the book (Wheeler and Shearar, 2005) and the circumstances of its publication.
\end{abstract}

Key words: Book review, white South Africa, Department of Foreign Affairs, external relations.

\section{INTRODUCTION}

The book's title, History of the South African Department of Foreign Affairs, is a misnomer because the greater part of its three parts and 28 chapters comprises a history of white South Africa's external relations between 1927 and 1966 based largely on departmental files, with a discussion of the department's administrative history and structure up to 1993 filling the final seven chapters and 178 pages. It is a weighty affair. Although only a paperback, it weighs in at $1.145 \mathrm{~kg}$ and measures 23.9 $\mathrm{cm}$ by $16 \mathrm{~cm}$ by $4 \mathrm{~cm}$. It contains 659 pages of text and 119 pages of foreword, table of contents, annexures including a bibliography, and an index. According to the foreword, it is the product of six years research ${ }^{1}$ by four researchers - one serving ${ }^{2}$ and two retired ${ }^{3}$ Afrikaans-

\footnotetext{
*Adapted from a paper presented to a biennial conference of the Australian Historical Association

${ }^{1}$ Internal evidence suggests that it was more like five years.

${ }^{2}$ At least at that time: Dr FJ Nöthling, who wrote chapters 6, 7, 12, 13, 14, 15, $16,17,18,19,20,21,22$, and 23, or half the book.

${ }^{3}$ Prof CJF Muller and Dr AJ van Wyk. The former wrote chapters 1, 8 and 9 and the latter chapters 2, 3, 4, 10, and 11. Prof Muller and Dr Nöthling were jointly responsible for chapter 5 .
}

speaking members of the history department at the University of South Africa in Pretoria and an Afrikaansspeaking member of the department's administrative staff up to $1993 .{ }^{4}$ Their ethnicity is mentioned because it, if not their political leanings, influenced the contents of the book which was originally written in Afrikaans and translated into English by a retired Foreign Service officer.

There is, for example, the inclusion of the Afrikaner diaspora in East Africa, Angola and Argentina (but not the United States). The work also incorporates the obligatory nod for nationally-minded Afrikaners towards the spectre of the lost republics. The first sentence of the text (3) nails the colours to the mast: "The origins of the South African foreign service date from the middle of the 19th century and may be linked to the Boer Republics in the Transvaal and the Orange Free State." The point is driven home at the end of the book (631): "The establishment of a Union High Commission in London in 1910 restored the practice of the former Boer Republics

\footnotetext{
${ }^{4} \mathrm{JH}$ de Beer, who wrote chapters 24, 25, 26 and 27.
} 
which had opened diplomatic and consular missions abroad as early as 1897 (that is four decades after the mid-19th century). However, those who are not ethnic Afrikaners should have no problem dating the Foreign Service's origins to 1927.

\section{Ancien régime's spin}

In essentials, the book is the ancien régime's spin on white South Africa's early external relations based on files of the Department of External Affairs, commencing in the dying years of the old régime and completed, belatedly, in the first years of the new. That alone makes it an unusual official institutional history. Although relatively bloodless, the democratization of South Africa at the end of the 20th century was the outcome of one of the world's great revolutions. One might think it surprising that historians commissioned by the last Afrikaner Nationalist régime should be allowed to continue their work by the latter's sworn enemy, the ANC, to which it capitulated and which possessed a different world view. Also surprising is that the fruits of their labours should have been published, with the new government's blessing, as long as eleven years after the ancien régime passed into limbo instead of, as should logically have happened, preceding that event. What is not surprising is that the new authorities did not fund the work. That would have been too much to expect and, thanks to "a generous grant [apparently R50 000] from the Anglo American Chairman's Fund" ${ }^{5}$ the South African Institute of International Affairs (SAllA) eventually picked up the tab and holds the copyright.

Writing tongue-in-cheek in The Daily Telegraph (2 November 2004, "History as written by the victor"), Max Hastings calls David Reynolds's masterly dissection of the writing of Winston Churchill's six-volume History of the Second World War "the longest-ever book review". Constraints of time and space curb whatever ambitions the present writer may otherwise have cherished along those lines in respect of the work under discussion. Instead, it is proposed to confine this review to a few salient features.

\section{Structure}

The book's structure is idiosyncratic. Commenting in 1999 on the early manuscript which had been submitted to him in his then capacity as General Editor of the Macmillan "Studies in Diplomacy" series, Prof GR Berridge of Leicester University held up Zara Steiner's The Times Survey of Foreign Ministries of the World ${ }^{7}$ as a benchmark. He said:

\footnotetext{
${ }^{5}$ Introduction: ix.

${ }^{6}$ (2004). In Command of History: Churchill fighting and writing the Second World War. London: Allen Lane.

${ }^{7}$ (1982). London: Times Books.
}

The long historical essays in [Steiner's] volume take as their theme the sort of essentially bureaucratic subjects which dominate in Part III of [the South African] book, with the foreign relations of the country in question merely providing the context. In [the South African] manuscript by contrast, the history of South Africa's foreign relations is the dominant theme, with the Department itself serving as not much more than the chorus until the end, when it appears as a massive appendix. ${ }^{8}$

Berridge said that he could not publish a book in that form. He recommended instead a work of two volumes, each of around 80000 words, the first to be called "The Department at Home" which would deal with the department's creation, administration and development, and the second "The Department Abroad", dealing with the diplomatic side including the opening of missions. Nothing came of that, and while the manuscript was shortened, its structure and number of chapters was retained. It is not evident why the book should have followed such a structure, Prof Berridge has commented:

I found the structure of the book just what I would have expected a committee to have designed, and the quality of the chapters variable, to say the least. Quite a lot were just narratives of the dreariest and driest kind imaginable. Whether the worst have been chopped out I do not know. ${ }^{9}$

The directive to the historian commissioned, Prof CJF Muller, who, if he had not died just over a year after he began his research, could well have been the book's sole author, did not stipulate that what was required was a history of the country's foreign relations instead of one focusing on the development of the department itself. It read:

After consultation of all available and relevant documents concerning the Department of Foreign Affairs, the history of the said Department must be compiled scientifically and the main currents and cardinal facts from 1927 reflected as accurately as possible in rounded form. ${ }^{10}$

It seems that Prof Muller and his successors took the bit between their teeth and bolted to the foreign relations side, while the departmental editorial committee not to mention management itself, lacking clarity as to what they wanted, failed to curb the authorial team and point it in the right direction. In any case, the principal source for

\footnotetext{
${ }^{8}$ Personal communication Berridge GR/de Wit PJ: 12 October 1999.

${ }^{9}$ Personal communication: 9 December 2005.

${ }^{10}$ Foreword: xi.
} 
this work is a mass of departmental files. That is the obvious source for an administrative history of the department but inadequate if those files should be the only primary source for a history of the country's foreign relations. For that, the net would need to be cast wider. Other countries' diplomatic records should be consulted to give the work perspective and depth. After all, as Kipling said, "what should they know of England who only England know?"

\section{BG Fourie}

The comments of Hugh Gilchrist, a First Secretary and Acting Australian High Commissioner in South Africa, on the appointment of BG Fourie, later fourth Secretary/Director-General for Foreign Affairs (1966-82), as Permanent Representative to the United Nations in 1958, illustrate the value of consulting other countries' diplomatic records. CFG von Hirschberg, who knew Fourie well in the 1950s besides being one of his Deputy Directors-General between 1978 and 1982, has said of Gilchrist's remarks: "The 1958 Australian view of Brand Fourie is spot on. It is a remarkably exact analysis of him."12

Gilchrist set the scene with these earlier observations:

Fourie is an ambitious and inscrutable man of about 42, deferential and smiling to members of the diplomatic corps, but much disliked by his departmental colleagues, some of whom consider him to be a ruthless little opportunist. $\mathrm{He}$ is of little value to us as a source of information on his department's thinking, since he evades virtually all types of question. Some of his colleagues have expressed the opinion that he is at least as close to Louw in the formulation of policy as Jooste is, if not closer (National Archives of Australia (NAA), 1958; Memo 349).

He rounded off his portrait after the announcement of the appointment:

By comparison with that of most of his colleagues in the Union Department of External Affairs, Fourie's rise has been rapid. Allowing for a natural element of jealousy on the part of some of his colleagues, it cannot be said that Fourie is well liked by many of them. From hints

\footnotetext{
${ }^{11}$ (1891). The English Flag. At least, that would apply to independent academic researchers. It is probably the counsel of perfection to expect such objectivity from the institution commissioning the work, despite the assertion in the latter's foreword (xiii) that it "offers ... a balanced factual account". Ironically, the foreword goes on to complain that the history of South Africa's international relations "was often viewed through the one-sided perspective of the colonial powers."

${ }^{12}$ Personal communication 18 August 1994.
}

dropped to us from time to time, it appears that his working methods aroused some hostility at the Counsellor and First Secretary level. It seems fair to say that Fourie is extremely ambitious and has pursued the ideal of departmental advancement with considerable determination.

Early in 1957 a 'Special Problems' Section was created in the Africa Branch. Fourie is said to have utilised this section as a means of attracting to himself, by familiar departmental devices, a good deal of control over other branches of the Department. ${ }^{13}$ This created so much trouble with other Assistant Secretaries that eventually the 'Special Problems' Section was abolished.

Fourie is undoubtedly a hard worker, and is reputed to be something of a perfectionist as regards drafts submitted to him. His memory of detail is extremely good. He is pleasant and extremely courteous in manner, but often diffident in conversation with foreign representatives. Despite an ever-ready smile, his personality is rather negative and elusive. He speaks in a rather high-pitched voice with a noticeable Afrikaans accent. ${ }^{14}$ As a rule, he is not a good conversationalist, and we have found it difficult to detect in him a continuing interest in any subjects except his work and his golf (at which game he is proficient) and the contemplation of flora and fauna, especially in remote bushland places.

A notable characteristic of Fourie is the rather obvious manner in which he steers the conversation away from any matter which he does not wish to discuss. We, and others, have found him preternaturally cautious about expressing any views on official matters, even of a non-confidential nature. If he has any personal views on South African party politics, he keeps them closely to himself; possibly they are opportunistically formed. His own colleagues state that he does not discuss official matters with them except on a 'need-to-know' basis. Members of Commonwealth diplomatic missions in South Africa have felt that his evasiveness in conversation on minor matters has sometimes been overdone to an irritating degree. It is

\footnotetext{
${ }^{13}$ The extensive listing of the section's tasks on National Archives and Records Service of South Africa (NARS). (1956). BTS. S4/5/2. 19. "Political Section (Special Problems" suggests this allegation was not unfounded.

${ }^{14}$ There was, however, nothing wrong with his English. For an example of his written English at an early stage in his diplomatic career, see his memorandum dated 1 April 1948 on the Atomic Energy Commission attached to NARS. (1948). BTS. 136/4/26. 2. Jacklin/SEA: 2 April.
} 
possible, of course, that it his new post he will blossom out and be more forthcoming.

It has long been obvious that Fourie has the full confidence of his Minister, Eric Louw, and undoubtedly exercises much influence in the presentation of policy matters for Louw's consideration. He is generally regarded by the diplomatic corps here as a possible future Secretary for External Affairs (National Archives of Australia (NAA), 1958; Memo 519). ${ }^{15}$

The files contain many accolades to Fourie, one of the most competent and internationally respected South African Foreign Service Officers of his generation. ${ }^{16}$

\section{THE HISTORIANS' QUALIFICATIONS}

Then there is the matter of the historian's qualifications. They were domestic historians, Prof Muller a distinguished one, "one of the world's experts on the Great Trek, that is Nineteenth Century South African history." ${ }^{17}$ But that did not necessarily qualify him to write authoritatively about international relations, even South Africa's international relations. By the same token, one would not expect an expert on international relations to write authoritatively about the Great Trek. DP Heatley spoke of the "the habit of mind that is required for appreciating questions of foreign policy" ${ }^{\prime 18}$ and GA Craig of the need to understand the nature of the diplomatic process, qualities, he felt, were essential for historians of international relations. ${ }^{19}$ There is no evidence that the authors of this book were even conscious of such requirements.

One suspects that the department would have been better served if it had invited a professor of international relations at a South African university to set its history as a post-graduate (MA or $\mathrm{PhD}$ ) topic and put a bright student to work. That, more or less, is what the Mount Lyell Mining and Railway Company did in far away, long ago Australia when its Chairman, WE Bassett, approached the Professor of History at Melbourne

\footnotetext{
${ }^{15}$ Fourie returned to South Africa at the beginning of 1963, was appointed Secretary for Information that year and in 1966, upon GP Jooste's retirement, Secretary for Foreign Affairs, a post subsequently renamed Director-General for Foreign Affairs. On his retirement in 1982, Fourie succeeded DB Sole as Ambassador to the United States, only his second time as Ambassador in a thirty-six year career in the department's diplomatic wing. He had been on the clerical staff for some twelve years before that

${ }^{16}$ United Nations Under-Secretary-General Brian Urquhart, who first met Fourie at the UN in 1945, called him "a decent and honorable man, personally dedicated to finding a proper solution for the Namibian problem, but constricted by the policy and politics of South Africa." Urquhart B (1987). A life in peace and war. London: Weidenfeld and Nicolson: 310.

${ }_{17}^{17}$ Annexure D: 737.

${ }^{18}$ Quoted by Craig GA (1979). "On the Nature of Diplomatic History: The Relevance of Some Old Books.” In Lauren PG (ed) Diplomacy: New Approaches in History, Theory, and Policy. London: The Free Press: 22. ${ }^{19}$ Ibid.
}

University, RM Crawford, who set the company's history as an MA topic for his promising student GN Blainey. First published in 1954 under the title The Peaks of Lyell, the book has so far achieved five editions (1954, 1959, 1967, 1978 and 1993) and marked the beginning of the now 83 year-old Blainey's lengthy career as one of Australia's greatest historians. ${ }^{20}$

But the old South African department was never historically-aware. Having in the 1980s denied scholars all access to its records, even those falling outside the so-called 30-year rule, it was not without irony that less than a decade later it should itself have commissioned a history, even if its management lacked the expert knowledge of whom to approach. Why was Prof Muller selected? ${ }^{21}$ His was the primary appointment and the others flowed from it. Contrary to the assertion in the foreword that the idea of the history was broached in 1984 by the then Foreign Minister, RF Botha, it seems that a departmental history was originally proposed by retired official DB Sole at a social function in Cape Town on the occasion of a heads of mission meeting a few weeks after FW de Klerk's historic 2 February 1990 statement. Sole recommended that the book be undertaken by an English-speaking academic, a political scientist at the University of Cape Town. Prof Muller began work in July 1991. If the matter had been raised as early as 1984 , it is difficult to understand why work was delayed for seven years, until 1991, the eve of the régime's supersession by the African National Congress (ANC).

\section{THE SHAPE OF THE FUTURE SOUTH AFRICA}

Of course, it was too early at that time to predict the shape of the coming South African dispensation. Powersharing, designed to keep it in power forever, was the ruling National Party's policy of the day and undoubtedly contributed to De Klerk's victory over his white opponents in the 1992 referendum. Early in 1992, repudiating Opposition accusations that the government intended handing over power to the ANC, the Minister of Law and Order, HJ Kriel, averred:

we are going to share power in this country. ... We are going to share it - not surrender! Let the ANC also take note of this. We are not handing over the country. We are in the process of negotiation on how to share power in this country. It is possible that the ANC can form part of a successive government, but ... the NP will form part of that government too. We shall not

\footnotetext{
${ }^{20}$ Blainey wrote in the Preface to the first edition that the compilation of the company's history took two and a half years.

21 His daughter, an academic political scientist, seems to have been the intermediary. She was approached by an academic political scientist in the employ of the department.
} 
agree to a new constitution or a new transitional government unless the rights and say of minorities are properly entrenched. There is no question of this. ${ }^{22}$

Yet, when push came to shove, De Klerk capitulated completely. Even Pinochet in Chile ensured for himself, if not the armed forces per se, a role that was written into the constitution. White Rhodesia and white Algeria, fought themselves to a standstill. Alone among such lost causes, white South Africa proved unexpectedly ephemeral. It ended, not with the bang confidently predicted down the years by those deceived by the rhetoric of Afrikaner Nationalism, ${ }^{23}$ but with the proverbial whimper. That lay in the future. At the beginning of the 1990s, while presumably conscious of vague intimations of impending mortality, DFA management probably thought there was enough time before the deluge, not that it would necessarily have been possessed by visions of deluges, for the history to be researched, written and published.

\section{PJ de Wit}

The speed of events left the history and the historians dangling, where they would quite likely have remained if had it not been for the so-called project officer, PJ de Wit, who assisted the historians in an administrative capacity. ${ }^{24}$ There was no question of publication, or even of completion of the work, by the new authorities. Although in retirement, it was De Wit who doggedly took upon himself a lengthy search for a publisher, drawing several blanks before connecting, through intermediaries, with the SAIIA in 2004.

In the nature of things, since his name appears on the cover as editor, this will probably be known as "Wheeler's book" or "the Wheeler book". ${ }^{25}$ As editor, his name will certainly appear in citations. However, if it is anybody's book, it is PJ de Wit's book. Without De Wit's persistence and determination, it is questionable whether the book would have been published at all. $\mathrm{He}$ is, in fact, the hero (or anti-hero depending on one's point of view) of the exercise. His search for a publisher took longer than the book did to research and write. He contributed the fivepage foreword. In the circumstances, he can be forgiven its pervasive air of triumphalism and self-congratulation. It

\footnotetext{
${ }^{22}$ House of Assembly Debates (1992). 31. 29 January: Col. 283.

${ }^{23}$ An example of that is BJ Vorster's (prime minister 1966-1978) assertion during an election speech: "Let the world know tonight, let it know for all future time to come, that small as we are, situated as we are, we will fight to the end with all we have got". (The Times (London) (1983). 12 September: Obituary.) That was an article of faith with most white South Africans and many others besides.

${ }^{24}$ De Wit had been a member of the department from the early 1950s to the mid-1960s when he transferred to another government department. He rejoined foreign affairs in a temporary capacity in the early 1990s.

${ }^{25}$ Wheeler is a 42-year Foreign Service veteran - 33 years under the old régime and 9 years under the new.
}

is not known why De Wit took so proprietorial an interest in the official history of the Department of Foreign Affairs. Perhaps he thought he made a mistake leaving that department and was glad to return to it in whatever capacity in his retirement. There is even a reference to him in the text of the book (265) to the effect that he joined the department in 1952 with "the sole aim of helping form an Africa section". The contributors' notes (741) hold that, on joining, he "was given the task of establishing the Africa Section of the Department". ${ }^{26}$

\section{Notes on Contributors}

In addition to pieces about the actual authors including the penultimate white Director-General, who contributed the 5-page superficial overview of the period covered which forms the final chapter, other notes included in the seven pages of Notes on Contributors relate to the editor; his wife; the (heroic) translator; and the project officer in charge of administration. There is no note on the archivist who now heads the departmental archives, who rounded up the files and whose contribution was indispensable. $\mathrm{He}$ is not alone in being denied a CV. On the evidence of the foreword, at least four non-authorial academics were essential to the publication of the book. So why include other non-authorial contributors and omit these? In consenting to publication, a Deputy Minister of Foreign Affairs, as well as the department's Director-General, performed important roles, and deserve write-ups as much as any. The same could be said of the four member departmental editorial committee - in addition to the translator - listed on page xi. Of course, so comprehensive a set of notes would be bizarre. Perhaps it would have been better just to confine the biographical details to the actual authors.

\section{Appearance}

The book's appearance is among its positive aspects. Its appearance is first-class. Printed on good-quality paper with a clear serif type-face, with footnotes rather than endnotes, the text, if not its content, is easy on the eye. Prof Berridge spoke well of the manuscript's style, calling it "uniformly crisp and clear", adding that "both authors and translator deserve congratulations for this". ${ }^{27}$ Although a paperback, the binding is good and designed to last. The index is comprehensive.

\section{Nuggets}

There is also the occasional nugget, one such being Nöthling's reference (512) to Diplomatic Cadets in

\footnotetext{
${ }^{26}$ An important assignment for a new recruit, a young Cadet. In fact, the section was started by two more senior officials, with De Wit as their Cadet.

${ }^{27}$ Personal communication Berridge/De Wit: 12 October 1999.
} 
centres such as Elizabethville and Leopoldville in the Belgian Congo having to compete for girls "with better paid bank clerks, shop assistants or artisans, unless they wished to spend their evenings in their hotel rooms" and were frequently "obliged to pay their calls on bicycles since they could not afford cars". That would be part of the austerity Van Heerden mentions in the final chapter (638), the parsimony which directed government spending in the 1950s. Whatever might be thought of its social and racial policies, the South African government of the 1950s was a model of financial probity and rectitude compared to its more recent successors up to 1994, which were much more profligate and cavalier in their attitude towards public money.

The 1950s were certainly a less profligate time in South African diplomacy. The Secretary for External Affairs, DD Forsyth, circularised missions in 1949 stating that the department would "during the next twelve months at least, unhappily be unable to consider any proposals involving either the augmentation or the transfer of staff, save in the most exceptional and unavoidable circumstances" (NARS, 1949). The situation seems to have deteriorated because he spoke two years later of the 1950 freeze on expenditure when even an officer "found guilty of misconduct" could not be recalled to the Union "because we had not the money to pay for his passage!" (NARS, 1951). In 1956 External Affairs Minister Eric Louw decreed that meeting various South African sporting teams on arrival at Sydney was not a legitimate object of official expenditure. Nor was High Commissioner Uys's attendance of that year's rugby tests (NARS, 1956). There would have been an outcry if such standards had been applied later. However, since his term and the terms of his two immediate predecessors as Director-General fell within the era of the "Imperial Foreign Ministry", which complemented PW Botha's "Imperial Presidency", Van Heerden's claim of "persistent austerity" throughout the period 1927-1993 is not supported by facts.

\section{Some nooks and crannies}

Peter Heather said of Robin Lane Fox's The Classical World: An Epic History from Homer to Hadrian (London: Allen Lane, 2005): "This is not a small book - nearly 600 pages of text, plus notes. Even so, the topic is huge, the best part of a millennium." And,

Ancient history lives for Robin Lane Fox and he makes it live for his audience. He knows all the main sources, and can also find his way to the nooks and crannies, such as the piece of clay tablet on which a scribe recorded the death of Alexander, together with the weather: 'Clouds'. The Classical World is a terrific read (The Sunday Times (London), 2005).

Sadly, little of this is true of the History of the South
African Department of Foreign Affairs. If, at a stretch, the authors can be said to know all the main sources, in the sense of having been allowed full access to the department's documentary records, they lacked experience of international relations to be able properly to interpret them, let alone being able to find their way to the nooks and crannies. Awareness of those could have improved their work.

\section{Anthony Hamilton}

Take the case of Anthony Hamilton, the third South African High Commissioner to Australia (1957-61). Nöthling claims he joined the Department of External Affairs "in London in 1944 having served in the British Foreign Office" (491.) Prof Muller had said in an early draft chapter that he had joined from the British Diplomatic Service. Such assertions, coupled with the claim that Hamilton was required to complete the South African department's so-called academic requirements, would not have been made by writers au fait with international relations. For the idea of a fully-fledged member of the British Foreign Office or Diplomatic Service joining the fledgling South African Foreign Service and being compelled "to complete the South African requirements under Departmental supervision" borders on the grotesque. Hamilton had, in fact, been a locally-recruited member of the British High Commission in South Africa and joined the South African department in Cape Town. In any event, he would not likely have been acceptable to the FO which, apart from anything else, required success in a competitive examination as well as a high standard of fluency in French and German. There was the case of Francis Stuart, who transferred from the British Consular Service to the Australian Foreign Service at the end of the Second World War, but the then separate Consular Service was a vastly different proposition to the Foreign Office and Diplomatic Service, ${ }^{28}$ and Stuart was invited to join the former only because its list had been extended (Stuart, 1990, 1989). Of course, other Australians or Australian-born men had earlier been taken up in the FO - the Leeper brothers and David Kelly are examples.

Anthony Hamilton entered the Department of External Affairs on 3 October 1944 as a Legation Secretary, a rank converted later to Second Secretary, at the age of almost 35 at a salary of $£ 600$ per annum. That was brought up by means of a personal non-pensionable allowance to $£ 800$, the maximum of the Second Secretary's scale. He had received $£ 800$ as locallyrecruited press officer and political adviser at the British High Commission a capacity in which he was employed from 1939. He claimed to have written "most of the

\footnotetext{
${ }^{28}$ As Michael Binyon pointed out in The Times (London) (2006): 29 March ("Diplomatic baggage that has to go"): "High-flying diplomats have traditionally looked down on lowly consular officials."
} 
political and economic despatches emanating from that Office" in that period (NARS, 1944a). That may have been an exaggeration. ${ }^{29}$ Even so, his well-argued motivation of the proposal he made within days of joining the department for the establishment of a political section confirms his experience in the field (NARS, 1944c). His link with GP Jooste, his first boss, dated from that time. He later served briefly under Jooste in Washington, DC.

For three years before joining the British High Commission he wrote leading articles on international and economic subjects for the Cape Times. That brought him to the attention of General Smuts who, he says, encouraged him to take the job at the High Commission (Personal communication, 1993). Before that for a year he had assisted Sir Howard d'Egville, the longtime Secretary-General of the Commonwealth Parliamentary Association (Personal communication 28 October 1993; NARS, 1944b, 1944d; Hall, 1971). In 1944 he discussed possible employment with the Argus company (NARS, 1944) but External Affairs was "very keen on getting" him and urged the Public Service Commission to give him "as high an allowance or salary as possible NARS, 1944d).

A week after he joined it, the department supplied the Commission with pro forma reasons for his appointment:

The anticipated post-war reopening and extension of the Union's diplomatic representation abroad necessitates the addition to the nucleus of staff trained in diplomatic duties of a certain number of officers in the higher graded posts. Mr. Hamilton was considered to be the best qualified candidate available for appointment to the post in question (NARS, 1944e).

That contradicted the department's previous line that the "Diplomatic and Consular service was a specialised service and that in respect of promotion, for example, preference should be given to officials who were already in that service" (NARS, 1937). Be that as it may, it was a lucky break for Hamilton because nine years earlier he had been among sixty-four applicants for the position of Probationer Diplomat and had been rejected. ${ }^{30} \mathrm{He}$ had applied from London while working for the Commonwealth Parliamentary Association. The four men who were accepted at that time included JE Bruce and $\mathrm{RH}$ Coaton who subsequently made their careers in the Foreign Service.

The holder of a BA and a B Com, Coaton had been a Clerical Assistant, Grade II, in the Department of Commerce and Industries, ${ }^{31}$ while External Affairs was

\footnotetext{
${ }^{29}$ His report on the Malayan independence celebrations, which the department circulated to all missions, is an example of his reporting. NARS (1957). BTS. 91/8/1. 10. Circular Minute A.46: 18 October.

${ }^{30}$ A list of the sixty-four applicants is attached to NARS (1935). BTS. S4/5/2. 2. Secretary, PSC/SEA: 24 September.

${ }^{31}$ A departmental memorandum early in 1936 described Coaton as "extremely able, and in all respects suitable for a post of attaché". There were "few
}

Bruce's first job (NARS, 1935a).

GJJF Steyn, much later Secretary for Commerce and Industries, was rejected then but accepted two years later. Quite likely Hamilton and Piet Beukes, ${ }^{32}$ who applied from England in 1936, were at a disadvantage for not being in South Africa when they made their applications. Charles te Water, the High Commissioner in London, interviewed them both. He described Hamilton as "above the average intelligence; well-educated and good address and manner". His teacher at Oxford, Pares, had said that "while he must admit Hamilton has not quite first class mind has nevertheless qualities which ought to stand him in good stead in diplomacy" (NARS, 1935b). They did. In any case, he did better for himself as a late entrant than if he had joined the department in his midtwenties. For instance, on entry he was paid a higher salary than either Coaton or Bruce who were promoted to Second Secretary only in 1946, the former on 1 January and the latter on 1 October (NARS, 1947). At the time of his promotion, Bruce's salary was £440 (NARS, 1947) and Coaton's would have been similar.

Commenting on the manuscript of the History, Prof Berridge made an interesting point about

Eloquent silences. One rather has the impression from this work that there were never any political conflicts within the Department, or between the Department and the National Party government (especially in the late 1940s/early 1950s), and that the only problems were caused by poor pay and conditions and personality clashes! $!^{33}$

That could well have been the case. There were, however, Foreign Service Officers who made no secret of their anti-government leanings, one such being Anthony Hamilton.

\section{CONTEMPORARY WHITE SOUTH AFRICAN MORES}

Not unnaturally the Foreign Service reflected the mores operative in white South African society at large. In April $1956 \mathrm{JK}$ Uys enquired from Australia what his attitude should be towards non-white diplomats, citing the fact

officials of the rank of Second Grade Clerk who were in general so suitable as he for the purposes of our diplomatic services". NARS (1936). BTS. S4/5/2. 2. Muller/Under-Secretary: 2 April (Original in Afrikaans.)

${ }^{32}$ Then a Rhodes Scholar, Beukes later became editor of the United Party newspaper Die Suiderstem and other publications. Charles te Water said he had "made a very favourable impression" and was "the type we require in our service". He recommended that Bodenstein see him personally. Beukes also impressed CK Allen, the Warden of Rhodes House, who sang his praises to Te Water. NARS (1936). BTS. 24/2. 1. Te Water/ Bodenstein: 2 November and Allen/High Commissioner: 23 October. But his application was not successful. In retrospect, from what one knows of Beukes's subsequent career in journalism, and given his personality and sense of humour, he would probably have found Foreign Service too restrictive.

${ }^{33}$ Personal communication Berridge/De Wit (1999): 12 October. 
that dancing sometimes took place at receptions and pointing out that "In the Union mixed dancing is frowned upon. Indeed, it is strongly disapproved" (NARS, 1956a). After consulting inter alia with External Affairs Minister Eric Louw, MacDonald (Don) Spies, the Under-Secretary, replied a month later by way of a personal letter: "You will however realise what a sensation it would cause here if a photograph or report should be published of a member of the Uys family dancing with a non-white, and it is felt that you should tactfully ensure that something like that does not occur" (NARS, 1956a).

Another example is Information Officer Smith's alarm over a Moral Rearmament (MRA) film, "African Tale", shown in Canberra in July 1955 . He reported his impressions to the Director of the State Information Service, PJG Meiring. He said the implications were

most disturbing. Indeed, the message of the M.R.A., as conveyed by the film can only be said to be a complete contradiction of our Government's policy of Apartheid in that white and non-white are called to meet on the same social plane as equals ... ${ }^{34}$

He added ("nowise by way of any form of criticism") that the film depicted the GovernorGeneral attending a MRA event in the Cape Town City Hall. Sir Godfrey Huggins was a principal guest at a similar affair in Salisbury. In Johannesburg, several scenes in the film "showed Afrikaners on the platform of M.R.A. in open advocacy of its objectives".

Translate these as one might like, one inescapable deduction must logically be made, and that is, ultimately, complete social equality of white and anybody non-white.

... this highly dangerous doctrine affords the easiest possible channel for Communism to slide into all parts of Africa, without Russia lifting a single finger to promote its objectives by 'preparing the ground' (NARS, 1955).

Uys sent the letter to External Affairs, saying that Smith had drafted it after discussion with him and that its contents carried his approval. Besides alerting the department to a possible approach by Meiring, he wanted to bring pertinently to the attention of the Union authorities the fact that MRA activities could in the long term be dangerous for the Union "with its multiracial composition".

\section{EMPLOYMENT OF WOMEN}

White South Africa made no pretence of being an egalitarian society and its hierarchical, authoritarian and

\footnotetext{
${ }^{34}$ No hint there of the later concept "separate but equal."
}

paternalistic nature was mirrored in the early Foreign Service, then very much of a white male preserve. The reasons for excluding women were perhaps what a modern feminist would have expected:

if women are admitted to the Diplomatic Service, they would compete against the male personnel. A promotion line would have to be drawn somewhere for women otherwise it would be soon be found that a woman would be placed at the head of an office while male clerks would be her direct subordinates. To the best of my knowledge such a policy is rejected by all Government Departments. If a promotion barrier was set for women - say not above posts of Third Secretary - I believe that we would in due course receive incessant representations from such women to lift the barrier. It will be appreciated that such a position would have extremely adverse consequences (NARS, 1953).

EJL Scholtz, a Chief Clerk, Grade I, drew up the paper in which this appeared as a defence against charges by Supreme Court Justice KR Bresler that his daughter Claire had been misled. The University of Pretoria had admitted her for study towards the degree BA (Diplomatic) which he claimed External Affairs had "dictated" but she discovered in her final year that her gender made her ineligible for service in the department. The Public Service Commission referred this to the department for its comments. In its reply, the department mentioned the "aversion which the majority of men have to serving under women", that it could ill afford to lose trained personnel through marriage, and that "women cannot be suitably employed in certain consular posts and posts involving trade work". Rather disingenuously it denied having "dictated" the BA (Diplomatic) course to the university; the latter had instituted this "after consultation with the Department but not at its request" (NARS, 1954).

The Commission need not have asked. It knew what the position was. Only six years before, the Public Service Enquiry Commission had pronounced itself "unable to recommend that there should be any alteration in the present policy of not recruiting women for the Diplomatic and Consular Service". ${ }^{35}$

No doubt because its report was a public document, the Commission refrained from mentioning the aversion of men to serving under women, confining itself to the prospect of female officers leaving the service on marriage "even if the marriage bar were removed". There was also a problem of women not being so readily transferable as men. It conceded, however, that "women trained in the Diplomatic and Consular Service will

\footnotetext{
${ }^{35}$ UG. 54-'48. Sixth Report of Public Service Enquiry Commission. Cape Town 1948: 29, para. 204.
} 
become quite as efficient as men similarly trained". ${ }^{36}$

\section{JK Christie}

In general, while External Affairs Minister Eric Louw's officials saw him as a not unreasonable man, he could be difficult. There was the case of JK Christie whom he was instrumental in having removed from his post as Commissioner in Nairobi at short notice soon after he became Minister of External Affairs in January 1955 and transferred to the Department of Commerce and Industries. At first it seemed Christie would be appointed Superintendent of the Guano Islands off South Africa's east coast. The file is silent as to the reason for Louw's attitude. A note from Forsyth to his Under-Secretary, Spies, cryptically recorded: "Apparently this decision is based upon complaints, the nature and source of which I do not know." However, a postscript suggested Forsyth knew more than he was prepared to reveal in writing:

I understand Mr. Christie travelled on the same boat with the Minister as a fellow passenger as far as Mombasa last October, I think. Did Mr. Christie return from leave in the Union at about that time? If not, in what circumstances was he on the boat? (NARS, 1955)

It was common knowledge among External Affairs officials in the late 1950s that Christie, sailing tourist class, had omitted to pay his respects to Louw, a Cabinet Minister, albeit heading another department (Finance), who was a first class passenger on the same vessel. In the end matters probably worked out as Louw intended because Christie returned to the department after his forced departure, taking the place of $\mathrm{HH}$ Woodward, who replaced him in Nairobi, as Counsellor in charge of the International Organisations, Africa and Coding Sections. Just over a year later he was transferred on promotion to Berne, Switzerland, as Envoy Extraordinary and Minister Plenipotentiary and subsequently to Lourenço Marques as Consul-General.

\section{HH Woodward}

Quite likely because the facts supported him, Woodward's role in the Tambo/Segal visa fiasco did him no harm. After Sharpeville in March 1960 Oliver Tambo, Deputy President-General of the African National Congress (ANC) and Ronald Segal, Editor of the quarterly magazine Africa South, fled the country without passports or valid travel documents with the intention of going to New York to address the United Nations Security Council. For the South African authorities they were

\footnotetext{
${ }^{36}$ UG. 54-'48. Sixth Report of Public Service Enquiry Commission. Cape Town 1948: 29, para. 203 .
}

"agitators" (NARS, 1960a) and earnest attempts were made to have them returned under the Fugitive Offenders Act. These efforts were probably foredoomed to failure because the men's route took them initially through British-controlled territory and, as Sir John Maud, the British High Commissioner, told GP Jooste, the Secretary for Foreign Affairs, at the time, that the British government would most likely be acutely embarrassed if it should be asked to return them to the Union (NARS, 1960a)

At the end of March and during the first half of April 1960 HLT Taswell, the South African High Commissioner in Salisbury in the then Central African Federation, did what he could when Jooste asked him to intercede with the federal authorities to prevent the men, who later joined forces with another fugitive, Yussuf Dadoo, from entering the Federation. ${ }^{37}$ When they did so, he tried to have them returned to South Africa. Taswell's best efforts were unavailing. The Rhodesia Herald (18 April 1960) called the process, not that it was necessarily aware of his role, "A Gilbertian tale". In June the American Ambassador, Philip Crowe, complained separately to the department and to Louw personally that "he had tried very hard to persuade the State Department not to grant Tambo a visa on the grounds that he was a communist, the Ambassador specifically saying that he had no doubt on this point" (NARS, 1960b).

But, having done his best, the South African Legation in Cairo had let him down because in effect it denied that Tambo was a communist. He had thereupon been granted a United States visa. According to Louw's note of his conversation with Crowe a week later, the latter had wanted to help in the Tambo case but his efforts were frustrated by the South African Minister in Cairo who told his United States colleague there that "he had no reason to object if the American government wanted to help Tambo get to the United States" (NARS, 1960a). At that time Crowe was himself under attack in Die Transvaler for his contacts with the extra-Parliamentary Opposition. Louw subsequently issued a statement repudiating the newspaper (Die, 1953; NAA, 1960). In the first week of July a file note had Woodward denying the allegation. More importantly, however, the note referred to the existence of a secret American document, possibly a Central Intelligence Agency (CIA) report, claiming that the South African government had never called Tambo a communist. There was also America's "own revolutionary origins and consequent policy of keeping its doors open to political refugees" (NARS, 1960).

\section{Cadets}

Junior South African diplomats - Learner Diplomats,

\footnotetext{
${ }^{37}$ See various items on NARS (1960). BTS. 136/3/10. 1, 2, and 3 including Jooste's note of 31 March on Vol. 1 on his telephone conversation with Taswell and the latter's account of his actions (attached to Taswell/DEA, 19 April.)
} 
Probationer Diplomats or (from May 1945) Cadets probably deserve a study of their own. On entering the department, they were regarded with ambivalence. On the one hand they tended to be treated with disdain by senior officers at head office and abroad along the lines of the British Third Secretaries who were "treated as skivvies by old fashioned Ambassadors" (Moorhouse, 1977). On the other, there was a real need for their services as working members of their sections despite such occasional fantasies, in which the Public Service Commission concurred, as "the employment of Cadets abroad should be restricted as far as possible with a view to their entire withdrawal from your overseas service" and in respect of the desirability of avoiding "the employment of Cadets in those sections at Head Office where the foreign policy of the Union is formulated" (NARS, 1953; 26 February). This last suggests complete ignorance of the foreign policy formulation process. In fact, what the department told the Commission about its External Relations Section in 1935 remained valid both at home and abroad: "were it not for the services of the newly appointed probationer diplomats, who, of course, are not intended as permanent units of this section, the position would have been intolerable" (NARS, 1935).

In mid-1946, Spies, then Chief Clerk, was disconcerted to be told that a new Cadet's capacity for work was "just about zero" besides which he had little Afrikaans and no Dutch (It was contemplated posting him to The Netherlands) (NARS, 1946a). Although down the years some of his contemporaries if not his superiors would have considered this assessment to have ongoing validity, a forty year career took that Cadet to many countries and he was a (non-Ambassadorial) head of mission at least four times covering a period of many years. In fact, he spent most of his career abroad.

RF Botha, the later Foreign Minister (1977-1994), a Cadet in 1953, was also Pretoria University's cheerleader, a position requiring the incumbent to keep the enthusiasm of his team's supporters at peak during the annual rugby match against the University of the Witwatersrand. It was practice in those days for the universities to seek to capture their rival's cheerleader, a fate which befell both that year. Botha was carried off to Johannesburg and detained for forty-eight hours in one of the men's residences on campus (Die, 1953). The Department of External Affairs was not amused. Botha was required to give a full explanation for his absence and was reprimanded. An earlier incident had seen three Cadets engaged in a chicken-stealing expedition. Botha had more get-up-and-go than most of his contemporaries. While a Cadet he wrote short stories for an Afrikaans-language newspaper and magazines. ${ }^{38}$

\footnotetext{
${ }^{38}$ Examples of his work are contained in Die Byvoegsel tot Die Burger (1954): 19 June \& 30 October. (1955): 14 May, 8 \& 22 October. (1956): 31 March, 25 August, 15 September \& 24 November. and Die Huisgenoot (1954): 24 September, 9 October \& 31 December. (1955): 29 August \& 14 November and (1956): 5 \& 12 March.
}

In 1959 the captain of the departmental cricket team, a Cadet by name of Dick Hauptfleisch, committed suicide by jumping one night from the aperture over the wash basins in a second floor men's room in the West Wing of the Union Buildings, the department's headquarters, onto a ledge some feet below, above an inner courtyard. He may have thought he was aiming for the courtyard two floors down without realising that the ledge would break his fall. The distance was not great and he could have survived if he had landed on his feet instead of on his back and hitting the back of his head. Of course, it would have been pitch dark at the time. The body was found, by a cleaner, lying on its back half-on and half-off the ledge. After the body was discovered, a fellow Cadet, one of Dick's friends, wandered around the department saying he was seeking proof that Dick had not killed himself but had been murdered. Dick was a drinker and quite likely drunk at the time. He was also in debt and eagerly anticipated the transfer that never came.

\section{Van Wyk on Smuts and South West Africa}

Van Wyk uncritically accepts the view of Sole and David Friedmann, the South African Press Association correspondent in London during the Second World War, that Smuts somehow erred by disregarding Winston Churchill's supposed advice in 1943 and 1944 "to annex SWA without delay". He writes (212):

Churchill thought it was urgent and that there would be no opposition since Smuts and the Union were highly regarded by the Allied Powers. He foresaw endless problems after peace had been had been concluded with Germany. Smuts failed to react, preferring the future of the Territory to be decided by the outcome of the war and to be enshrined in the Peace treaty, a pure formality.

Supportive of Van Wyk's contention is Hancock who claimed that "Not a dog would have barked" if Smuts had annexed South West Africa. After all, the "Russians went unchallenged when they followed a different fashion in dealing with the Baltic States". But he did not do so because of his "old-fashioned respect for the legal fabric of the society of nations" (Hancock, 1968). However, the Soviet and South African situations were not analogous. The Soviet Union was a great power and the Baltic States lay outside the League of Nations mandates system. Assuming that Friedmann and Sole are correct, Churchill's advice could in some way have been connected to the British view, which the Colonial Secretary, Oliver Stanley, expounded to the Commonwealth Prime Ministers in May 1944 and later that year in the United States (British Commonwealth and Prime Ministers' Meetings, 1944; Louis, 1978; Hasluck, $1970)$, that the mandates system had served its purpose. 
Smuts himself said as much in the South African Parliament the same year (Slonim, 1973). ${ }^{39}$

Why did Smuts take the South West Africa question to the United Nations? He did so not because of his respect "for the legal fabric of the society of nations" nor, as Barber and Barratt (1990) suggest, because he "was confident of success", but because politically he thought he had no choice. ${ }^{40}$ Having tested the atmosphere at the first part of the General Assembly's first session (held in London from 10 January to 15 February 1946) at which the New Zealand's Prime Minister Fraser was South Africa's most vehement critic, Heaton Nicholls, who led the delegation, reported that

if the arrangements finally decided upon by the Union Government go beyond the terms of the present mandate, it will be necessary for these arrangements to be submitted for information and ratification by the General Assembly.

\section{Even if it should prove}

possible to obtain the tacit endorsement of the General Assembly for the Union's action [which, misguidedly, he thought might well be the case] without submission of a formal resolution for approval ... it would not be safe to proceed on the assumption that it will be possible to take action outside the terms of the mandate, without the General Assembly taking cognisance of such action (NARS, 1946b).

That was why Smuts went to the General Assembly. He had believed initially that the disposition of territories would be a matter for the peace conference. That had been the case at Versailles in 1919; but it was not in 1945 and he had no option but to follow Heaton Nicholls's advice.

Slonim raises the question whether the Smuts government canvassed the views of other UN members before submitting the matter to the General Assembly (Slonim, 1973). Under normal circumstances that would have been the commonsense approach. If, however, the government did not do so, it meant that it knew the answer. It may have seemed unfortunate from Smuts's point of view that the application for incorporation coincided with the Indian complaint about the treatment of South African Indians. But that was unlikely to have tilted the balance against him. Sentiment in the Assembly was in any case decidedly anti-colonial and in favour of all mandated territories being placed under trusteeship.

\footnotetext{
${ }^{39}$ In tying Smuts's remark exclusively to his concern about the future of South West Africa, Slonim is obviously unaware of the wider dimension.

${ }^{40}$ International Court of Justice. Reports of Judgments, Advisory Opinions and Orders. Legal Consequences for States of the continued presence of South Africa in Namibia (South West Africa) notwithstanding Security Council resolution 276 (1970). "'Dissenting Opinion of Judge Sir Gerald Fitzmaurice": 257 (245), para. 56 , fn. 34.
}

India's complaint merely added a further dimension. The British report on the proceedings of the second part of the first session held that the "South African case suffered from the feeling aroused by the Indian complaint ... as well as the 'anti-imperialist' sentiment of the Assembly, which was undoubtedly in favour of mandated territories being placed under trusteeship" (United Nations, 1946). As The Round Table observed at the time, "General Smuts's request [for incorporation] was rejected so decisively ... that rejection must have been inevitable" (The Round Table, 1947).

Sole places much of the blame on Smuts personally, writing that his approach to the issue was "doomed from the start". That inter alia because he did not take the advice of "so outstanding a statesman as Churchill", because "he was so completely out of tune with the temper of the times", because "he had little conception of the strength of anti-colonialist feeling", and because "he persisted in thinking that the methods and procedures of the postwar settlement would be broadly similar to what he had personally experienced at the end of World War l" (Sole, 1990). Not all of this is true. Churchill may have been an outstanding statesman but not in the colonial field where he had the reputation of being a reactionary. Like Smuts, Churchill was a child of his times. He may have counselled annexation, but it is another matter how reflective such advice was of opinion in his own government let alone in the Dominions at large. In any case, South Africa would have gained little more than a temporary respite if Smuts had annexed the territory during the war. The mass admission of African States to the United Nations in the 1960s would have seen to that. The anti-annexationists at the UN, including fellow Commonwealth members India, Australia and New Zealand, would probably have ensured that South Africa did not get away with it in the short term either.

Why did Smuts not simply fall in with prevailing international opinion and conclude a trusteeship agreement? Much (South African) ink has been expended since 1945 on showing that the government was neither legally nor morally obliged to do so. Even in 1990 Sole proceeded from the assumption that incorporation was the only acceptable solution. It is true that the trusteeship system was "voluntary". All that had happened was that machinery had been established at San Francisco which "might be used" (Gilchrist, 1945). But the United Nations is a political organisation and in the context of trusteeship, the dictionary meaning of "voluntary" was a dead letter practically from the start. In any case, Butterfield's view is not inapplicable: "it is possible for us to have the law on our side while the ethics of the case are against us" (Butterfield, 1960).

Was a trusteeship agreement ever a viable option? The key to the situation was the existence of a sizeable, vocal, not to mention self-governing white population in the Territory which markedly narrowed the South African government's options. Most commentators overlook the significance of that. White settlement in South West 
Africa was permissible because Article 22(6) of the League of Nations Covenant as well as Article 2 of the mandate instrument authorised the administration of the territory as an integral portion of the territory of the mandatory state. Not only was white settlement permissible but South Africa argued at the United Nations in 1946 and at the International Court of Justice in the 1960s, that it was necessary in order to develop the territory (United Nations, 1946). That was also its response to charges that it administered the territory for the benefit of the whites (Pienaar, 1987).

The existence of a permanent white population tied the hands of successive South African governments. Even though the government could, as Australia did, dictate the terms (Hudson, 1970), a trusteeship agreement was not considered a practical proposition. Carrying with it implications of a sell-out, an agreement would have meant domestic political disaster. A perception whites in South West Africa, most of them Afrikaners, were to be handed over to the tender mercies of the United Nations would at that time have had most adverse consequences for the perpetrator in the context of South Africa's domestic politics. By way of a contingency plan DD Forsyth circulated a draft trusteeship agreement prepared in his department to other departments and the South West Africa Administration early in 1946 (NARS, 1946c). Smuts could not afford to follow through on it. He was not expected to lose the 1948 general election, but negotiations with the UN over a trusteeship agreement would practically have guaranteed that. To that extent he can be awarded points for political nous. And even if an agreement had been negotiated it would not have been assured of an easy passage. That was Australia's experience (Hudson, 1970; Pyman, 1980).

\section{Nöthling on relations with Australia}

There is the matter of South Africa's relations with Australia. To this day, evidence of a friendly disposition on the part of Australians, especially one so elevated as Robert Menzies, the longtime Prime Minister, to what was at the time, as it still is, thought of as South Africa's "racist régime", is not well-received in Australian academic, media and political circles. Thus Nöthling's words (470) about the benign attitude of the Menzies administration towards South Africa would probably set present-day Australian teeth on edge:

Australia's actions were a consequence of its own racial policy and the trusteeship of Papua and part of New Guinea, which also brought it into contact with the Fourth (Trusteeship) Committee. It discriminated against its aborigines and its 'White Australia' immigration policy was strongly criticised by its Asian neighbours. Some compared it to apartheid, a policy Australia never supported, although it continued to be a staunch opponent of interference of interference in domestic affairs. ${ }^{41}$

The Menzies administration's support of South Africa at the UN, never as straightforward as Nöthling would have it, started breaking down in 1959 when, in response to Indian lobbying, and over British objections, the Australians switched their vote from negative to abstention on the substance of the apartheid item.

At least Nöthling recognised the access early South African High Commissioners in Canberra enjoyed to Robert Menzies. ${ }^{42}$ That is more than can be said for PG Edwards who held in his recent biography of Arthur Tange, the longtime Secretary of the Australian Departments of External Affairs and Defence, that only the British High Commissioner "had access to the Prime Minister" (Edwards, 2006). Menzies enjoyed the company of diplomats and was quite accessible to them, especially to Anthony Hamilton, who became a personal friend (Cain, 1997). Menzies was also accessible to Hamilton's predecessors Viljoen and Uys, even GC Nel as chargé d'affaires, but his relationship with them was not as close as it was with Hamilton.

Nöthling could have been kinder to Dr Evatt. Although that was not the case, Evatt thought Viljoen's appointment in 1949 was the direct outcome of his lobbying of Dr Malan on the occasion of his brief stopover in Cape Town at the end of 1948 for South Africa to open a High Commission in Canberra, and he sent Malan a message of appreciation. According to the Australian High Commissioner in South Africa at the time, Alfred Stirling, Evatt got on very well with Malan and Eric Louw during his stopover (Stirling, 1974). Thus the welcome accorded Viljoen in Canberra can hardly be described as "cool" (469). Evatt's tendency to elasticity in his interpretation of the Article 2 (7) of the UN Charter's on domestic jurisdiction, in the drafting of which he had a hand in San Francisco, can be attributed to his wish to safeguard Australia's domestic jurisdiction not that of other countries, rather than to his allegedly "great personal admiration" for India's Pandit Nehru.

\section{THE ROLE AND INFLUENCE OF THE AUSTRALIAN AND SOUTH AFRICAN DEPARTMENTS OF EXTERNAL AFFAIRS AND THE BRITISH FOREIGN OFFICE}

Edwards on Tange provides an interesting contrast between the role and influence of the Australian Department of External Affairs and its officials, especially its permanent head, and that of the South African department, its permanent head and officials. His book points to the marked difference between the Australian and South African public service cultures with reference

\footnotetext{
${ }^{41}$ Nöthling mentions that the South Africans were grateful.

${ }^{42}$ Even so, in the nature of things, it is not strictly speaking correct to say that Menzies "developed and maintained personal contact with Viljoen and his successors."
} 
to the two countries' Departments of External Affairs. The idea of a South African permanent head hanging on to his job for several years in the face of the Prime Minister's determination to remove him, as did Tange, would have been unthinkable. In the wider community, senior Australian External Affairs officials were, as they still are, perceived as persons of substance and note, which was hardly the case with their South African counterparts.

Australian scholarship in respect of that country's international relations is also more advanced than its South African equivalent, the said Edwards being a leader in the field. Biographies of key South African External Affairs officials lie in the future, assuming the South African academic tendency to focus on politicians rather than on officials can be overcome. A problem here is that white South African officialdom never enjoyed the status of its Australian and British counterparts and biographers have not so far considered South African officials to be worthy subjects. By comparison with especially the British Foreign Office and Diplomatic Service, only a handful of South Africans, mainly permanent heads, have written and published autobiographies. ${ }^{43}$

The contrast between the British Foreign Office and the South African department is stark. The establishment of a registry system in the Foreign Office in 1906, consisting of a central registry and three sub-registries, was more than just an administrative reform affecting the way papers were kept (Steiner, 1963). It changed the distribution of work. In terms of the new procedure, "when papers were sent to the Foreign Secretary a sheet was attached giving the opinions of departmental officials" (Cromwell, 1982). In that way the clerks became "advisers engaged in the policy-making process" (Steiner, 1963) or, as Jones says, "sat in judgement on dispatches" (Jones, 1983). Never again "were the permanent officials cut off from the nerve centre of political decision" (Steiner, 1963).

That points to the permanency of the Foreign Office's influence in relation to that of the politicians. Indirectly, it suggests a reason for Mrs Thatcher's complaint decades later that one of her Foreign Secretaries, Sir Geoffrey Howe, had fallen under the spell of the Foreign Office "where compromise and negotiation were ends in themselves" (Mason, 1994). While that may also have been true of the South African department (Schoeman, 1973), ${ }^{44}$ Bruce Lockhart's view of the Foreign Office could certainly not have been applied to the former:

The F.O. ... is very like the Vatican. They know that, wars or no wars, they will be there whatever

\footnotetext{
${ }^{43}$ The best of these is DB Sole's "This above all": Reminiscences of a South African diplomat, which was not published.

${ }^{44}$ Eric Louw said something similar in 1961 when the cabinet contemplated terminating South Africa's membership of the United Nations. He said officials would never recommend that South Africa leave the organisation because "that was the nature of the people in their profession."
}

happens. Even if Britain becomes a third-class power, there will be a Foreign Office, and it will be run very much on the same lines as it is at present. The professional members, too, are like the Italian cardinals. They run the show and have survived all the storms of criticism (Young, 1980).

In South Africa the clerks never became advisers, hardly "sat in judgement on dispatches", and any equation between the department and the Vatican would be risible. The registry in conjunction with the library was still the "most important factor in the Foreign Office" around the time of the South African department's creation in 1927 (NARS, 1927), and the Librarian and Keeper of the Papers was a man of considerable status (Tilley and Gaselee, 1933). ${ }^{45}$ Although the South Africans set up a registry or records section to manage and store the flow of correspondence, it was altogether lacking in influence as was its personnel in status. Its head was a female clerk.

\section{CONCLUSION}

Why did the South African ancien régime commission this book? De Wit's claim in the foreword (xiii) that "its primary purpose [was to provide] a scientifically compiled manual for training and motivating personnel" can be dismissed. The department hardly needed to employ three outside historians not au fait with international relations to spend five years producing a manual to train and motivate its personnel. It was quite capable of doing that itself at less cost. That was, of course, the old department. Missing from the foreword is any explanation why the new, post1994 department, should want to train its personnel with a one-sided account of white South Africa's early foreign relations.

The related claim that

the history project has served to advance a process launched in the Department to ensure proper care of the documents in its possession, to draw up an approved file register and to train staff in the service centre in the opening and closing of files and the arrangement of documentation according to archival principles,

can likewise be dismissed. All very commendable that the department should apparently only immediately prior to 1994 have launched a process to care for its files. In fact, such a process extended back to its beginnings.

What is missing from the foreword is a reference to the small team of retired officials of the former Department of Information (which merged with the Department of Foreign

\footnotetext{
${ }^{45}$ One of them, Stephen Gaselee, collaborated with a former Chief Clerk, the Rt. Hon. Sir John Tilley, on a study of the Foreign Office.
} 
Affairs in the late 1970s) employed in the dying days of the régime to comb through files and eliminate embarrassing material, an action recalling the Smuts government's removal of defence records after its electoral defeat in 1948 (Hartshorn, 1960) although hardly on the same scale. If the combing-out process had been a major operation, radical archivist Verne Harris would surely have mentioned it in his interesting chapter "They should have destroyed more': The Destruction of Public Records by the South African State in the Final Years of Apartheid 1990 to 1994" (Cox and Wallace, 2002; Harris, 2000) but he did not. For him, the principal offenders were the South African Defence Force and the National Intelligence Service.

Why did the ancient régime commission the book? A perception, perhaps, of writings on walls, if not of deluges. Well may one wonder whether, if Sole had not raised the issue early in 1990, the book would have come about at all. More interesting is why SAllA published it. The pre-1994 SAllA kept a distance from the old Department of Foreign Affairs and probably would not have touched this manuscript with a twenty-foot pole. How ironic, then, that the post-1994 SAllA should wax lyrical about the old department's commissioned account of the country's early foreign relations. In his Introduction to the book (xix), the SAllA National Director who accepted it for publication, expressed his delight in publishing it pursuant to the Institute's "mission of 'Explaining the World to South Africa and South Africa to the World'."

There exist a multitude of British biographical or autobiographical works giving a flavour of what Foreign Service was about for British diplomats at a given time. There are also many works which illuminate the evolution and workings of the Foreign Office, so much so that, ironically, South Africans know more, or at least have the opportunity to know more, about the Foreign Office and some of its luminaries such as Sir Eyre Crowe and Sir William Tyrrell than they do about their own Department of External Affairs and its officials. If the History of the South African Department of Foreign Affairs hardly lifts the veil, at least it is a start.

Despite their many flaws, Winston Churchill's six volumes on the Second World War allowed "the author to impose his version of history on the world" which has become "received opinion". No matter that Reynolds's recent

juxtaposition of the Churchill version of the war with the present corpus of knowledge leads to the inescapable conclusion that, valuable as the six tomes may be as insight into Churchillian psychology, they are almost worthless as history. ${ }^{46}$

\footnotetext{
46 "How Winston fixed the past", Frank McLynn's review of Reynolds D (2004). In Command of History: Churchill fighting and writing the Second
}

Likewise, despite its shortcomings, the History of the South African Department of Foreign Affairs 1927-1993 could well achieve a life of its own. It is, after all, likely to be the only comprehensive work in the field for a long time. And if, perhaps, the cognoscenti will, as one scholar did, find it "appealing ... in its own awful way," at least the files on which it is based are available to postgraduate students: pre-1965 at the National Archives and post1965 in the Archives of the Department of Foreign Affairs.

Perhaps the most surprising element of this book is not that departmental management should, at the eleventh hour, have wanted to erect a monument to mark the régime's passing, but that it should have been published as long as eleven years after the democratization of South Africa. PJ de Wit deserves much of the credit for that. From the ancien régime's point of view, the appropriate time for publication would have been pre- not post-1994. Possibly even more surprising is that the book should bear the imprimatur not only of the department's current management and therefore that of the present government, with the (false) implication that the old and new departments are one and the same, but also of the SAllA which published it and holds the copyright.

\section{REFERENCES}

Barber J, Barratt J (1990). South Africa's Foreign Policy: The search for status and security 1945-1988. Johannesburg: Southern Book Publishers in Association with the South African Institute of International Affairs: 22.

British Commonwealth and Prime Ministers' Meetings (1944). PMM (44). 10th meeting. 9 May: 1-2

Butterfield H (1960). International Conflict in the Twentieth Century: A Christian View. London: Routledge: 31.

Cain F (ed) (1997). Menzies in War and Peace, St Leonards, NSW: Allen \& Unwin: 29-31.

Cox RJ, Wallace DA (eds) (2002). Archives and the Public Good: Accountability and Records in Modern Society. West Conn./London: Quorum Books: 205-28.

Cromwell V (1982). "The Foreign and Commonwealth Office." In Steiner $Z$ (ed) (1982). The Times Survey of Foreign Ministries of the World. London: Times Books: 557

Die Transvaler (1953). 29 May. (1960): 26 March.

Edwards PG (2006). Arthur Tange: Last of the Mandarins. Crows Nest, NSW: Allen \& Unwin: 101.

Gilchrist H (1945). "Colonial questions at the San Francisco Conference", The American Political Science Review, XXXIX, 5(10): 988. Gilchrist had been Assistant Director of the Mandates Section in the League of Nations Secretariat. At the San Francisco Conference he was Executive Officer of Commission II.

Hall HD (1971). Commonwealth: A History of the British Commonwealth of Nations. London and New York: Van Nostrand Reinhold: xiv.

Hancock WK (1968). Smuts: The Fields of Force. Cambridge: University Press: 467 and footnote.

Harris V (2000). Exploring Archives: An Introduction to Archival Ideas and Practice in South Africa. (2nd ed). Pretoria: National Archives of South Africa: 73-74.

Hartshorn EP (1960). Avenge Tobruk. Cape Town/Johannesburg: Purnell \& Sons: 207-10.

Hasluck P (1970). The government and the people, 1942-1945. Canberra: Australian War Memorial: 488-89.

World War. London: Allen Lane. The Independent (London) (2004): 12 November. 
Hudson WJ (1967) “Australia's Trusteeship Policy”. Australian Outlook. 21. 1 (4): 14.

Hudson WJ (1970). Australia and the Colonial Question at the United Nations. Sydney: Sydney University Press: 83-86.

Jones RA (1983). The British Diplomatic Service 1815-1914. Gerard's Cross: Colin Smythe: 219.

Louis WR (1978). Imperialism at bay: the United States and the decolonization of the British Empire, 1941-1945. New York: Oxford University Press: 441-42

Mason B (1994). "Matters of tact." BBC Worldwide. 19(5): 18.

Moorhouse G (1977). The Diplomats: the Foreign Office today. London: Cape: 47.

NAA (1958). A1838/2, 916/1/2. Memo 519. Gilchrist/DEA: 29 August.

NARS (1927). BTS S4/5/1/1. 1. "Memorandum on Foreign Office Organisation."

NARS (1935). BTS. S4/5/2. 2. SEA/Secretary, PSC: 2 March. Muller/Under-Secretary: 2

NARS (1935a). BTS. S4/5/2. 2. Secretary, PSC/SEA: 22 November.

NARS (1935b). BTS. S4/5/2. 2. Telegram 410, Te Water/SEA: 5 November.

NARS (1937). BTS. S4/5/2. 3. Muller/v.d. Walt: 11 March (Original in Afrikaans)

NARS (1944a). BTS. S4/5/2. 7. "Anthony Albert Mordaunt Hamilton." NARS (1944b). BTS. S4/5/2. 7. "Anthony Albert Mordaunt Hamilton.

NARS (1944c). BTS. Hamilton. III. Hamilton/Assistant Secretary: 7 October. "Establishment of a Political Section in the Department."

NARS (1944d). BTS. S4/5/2. 7. Hamilton/Forsyth: 14 August. Pohl/Swart: 12 May.

NARS (1944e). BTS. Hamilton. I. Pohl/Secretary, PSC: 11 October.

NARS (1946a). BTS. S4/1/5/2/1. 3. Memoranda Louw/Spies: 6 May and Spies/Louw: 9 May.

NARS (1946b). BTS. 136/2. 1. Annexures. "Report of the First Meeting of the United Nations General Assembly held in London, January 1946": 12, para. 23.

NARS (1946c). BTS. 91/8/1. 2. Forsyth/All Heads of Departments of State: 28 January.

NARS (1947).BTS. S4/5/2. 11. Departmental personnel around April. Salary and other particulars regarding Montgomery, Viljoen, Van Heerden, Sole, Bruce, Stewart, Botha and Burger.

NARS (1949). BTS. 91/8/1. 3. Forsyth/All Heads of Mission. Minute PM 28/9; PM 45/1: 7 November

NARS (1951). BTS. Viljoen. 7. Forsyth/Viljoen: 5 April.

NARS (1953). BTS. S4/5/2. 17. "The question of the employment of women in the South African foreign service": 24 February. Secretary, PSC/SEA: 26 February.

NARS (1954). BTS. 24/2. 3. Spies/PSC: 11 March. Vol. 2 contains the department's correspondence on the subject with the University of Pretoria in 1950. No effort was made to turn the university from its course.

NARS (1955). BCB. 8. 8/12/ST. Smith/Meiring: 21 July.

NARS (1955). BTS. Christie. Forsyth/Under Secretary: 24 January.

NARS (1956). BCB. 21. 44/1, Spies/High Commissioner, Canberra: 27 April (original in Afrikaans) and BTS. 4/3/32. 2. Spies/High Commissioner, Canberra: 13 August.

NARS (1956a). BTS. 1/25/6. 1. Uys/Acting SEA: 24 April. Spies/Uys: 26 May.

NARS (1960). BTS. 136/3/10. 5. file note in Afrikaans, possibly drafted by K.E. Pakendorff, on Oliver Tambo: 6 July.

NARS (1960a). BTS. 136/3/10. 1. DEA/Permanent Delegation, New York, No. 35: 31 March. 2. File Note by GP Jooste: 1 April.

NARS (1960b). BTS. 136/3/10. Unsigned note to Stewart: 6 June.

National Archives of Australia (NAA) (1958). A1838/2, 201/9/1. Memo 349, 30 May: 2, para 6 .

National Archives of Australia (NAA) (1960). A1838/2, 201/8. Memo. 155, Davis/DEA: 4 April.

Personal communication 28 October 1993.

Pienaar (1987). South Africa and International Relations: 125.

Pienaar S (1987). South Africa and International Relations between the two World Wars: The League of Nations Dimension. Johannesburg: Witwatersrand University Press: Preface.
Pyman TA (1980). "The Australian Role in the United Nations as a Trustee State for Papua New Guinea. Australian Outlook. 34, 3 (12): 254-56

Schoeman BM (1973). Van Malan tot Verwoerd. Cape Town/Pretoria: Human \& Rousseau: 240.

Slonim S (1973) South West Africa and the United Nations: An International Mandate in Dispute. Baltimore \& London: 75, 81, fn. 2, 232

Sole DB (1990). "This above all": Reminiscences of a South African diplomat. Unpublished: 119.

Steiner (1963). "The Last Years of the old Foreign Office, 1898-1905." The Historical Journal. VI (1): 90.

Steiner Z (1963). "The Last Years of the old Foreign Office, 1898-1905." The Historical Journal. VI (1): 88

Stirling AT (1974). Lord Bruce: The London Years. Melbourne: Hawthorn Press: 431

Stuart FH (1990) (1989). Towards coming-of-age: a foreign service odyssey. Nathan, Qld.: Griffith University: 30

The Round Table (1947). 146 (3): 133.

The Sunday Times (London) (2005):11 December.

Tilley J, Gaselee S (1933). The Foreign Office. London: Putnam's.

United Nations (1946). Proceedings of the General Assembly. Second Part of the First Session (with annexes). New York: 23rd October16th December. London: HMSO 1947: 12, Annex G, para. 3.

Wheeler TF (ed), Shearar JB (trans) (2005). History of the South African Department of Foreign Affairs 1927-1993. Johannesburg: South African Institute for International Affairs. 778pp.

Young K (ed) (1980). The diaries of Sir Robert Bruce Lockhart. 2. London: Macmillan: 520. 